\title{
Association Between the Proportion of Sclerotic Glomeruli and Serum Creatinine in Primary Focal Segmental Glomerulosclerosis
}

\section{Primer Fokal Glomerulosklerozda Sklerotik Glomerül Yaygınlığı ile Serum Kreatinin İlişkisi}

\author{
Ashraf FAKHRJOU, Ahad HASHEMPOUR, Sepideh SHADRAVAN, Rohollah Fadaei FOULADI
}

Department of Pathology, Tabriz University of Medical Sciences, Imam Reza Hospital, TABRIZ, IRAN

\begin{abstract}
Objective: To evaluate the possible correlation between the extent of sclerotic glomeruli and the level of serum creatinine and its clearance rate in patients with primary focal segmental glomerolusclerosis.

Material and Method: In a cross-sectional study, 50 patients with biopsy-proven primary focal segmental glomerolusclerosis were recruited. The proportion of globally and segmentally sclerosed glomeruli was determined during the first histopathological examination of renal biopsy specimens. Correlations of these variables with on admission serum level of creatinine and its clearance rate were investigated.
\end{abstract}

Results: Twenty-four males and 26 females with a mean age of $39.82 \pm 16.45$ (range: 16-85) years were enrolled in the study. In a significant fashion, the proportions of segmental and global glomerulosclerosis were directly correlated with the serum level of creatinine and inversely with its clearance rate $(r=-0.43$ with $\mathrm{p}=0.002$ and $\mathrm{r}=-0.45$ with $\mathrm{p}=0.001$, respectively).

Conclusion: Apart from the degree of interstitial fibrosis, the serum level of creatinine and its clearance rate are well correlated with the proportions of both segmentally and globally sclerosed glomeruli in primary focal segmental glomerulosclerosis.

Key Words: Focal-segmental glomerulosclerosis, Creatinine, Creatinine metabolic clearance rate, Histopathology
ÖZ

Amaç: Primer fokal glomerüloskleroz olgularında sklerotik glomerul yaygınlığı, serum kreatinin düzeyi ve klirensi arasındaki ilişkiyi saptamak.

Gereç ve Yöntem: Bu kesitsel çalışmada, biyopsi ile doğrulanmış 50 primer fokal segmental glomerüloskleroz olgusu değerlendirildi. Global ve segmental skleroz gösteren glomerül oranı, olgulara ait ilk renal biyopsilerde değerlendirildi ve ilk başvuru sırasındaki serum kreatinin düzeyi ve klirensi ile karşılaştırıldı.

Bulgular: Yirmi dört erkek ve 26 kadın olgunun yaş ortalaması $39,82 \pm 16,45$ (dağılım:16-85) idi. Segmental ve global glomerüloskleroz oranı serum kreatinin düzeyi ile doğrusal, kreatinin klirensi ile ters bağıntı (sırasıyla $\mathrm{r}=-0,43, \mathrm{p}=0,002 ; \mathrm{r}=-0,45, \mathrm{p}=0,001$ ) gösteriyordu.

Sonuç: İnterstisyel fibrozisin derecesinden başka, serum kreatinin düzeyi ve klirens oranı, primer fokal segmental glomerülosklerozda hem segmental hem de global sklerotik glomerül oranı ile ilişkilidir.

Anahtar Sözcükler: Fokal segmental glomerüloskleroz, Kreatinin, Metabolik klirens hızı, Histopatoloji

\section{INTRODUCTION}

Focal segmental glomerolusclerosis (FSGS) was described for the first time in 1957 as a condition characterized by asymptomatic proteinuria or varying degrees of nephrotic syndrome with or without renal insufficiency (1). Although the diagnosis is made merely on the histopathological findings, the clinical symptoms could be regarded as precious (2). Probable contributing factors to primary

(Turk Patoloji Derg 2012, 28:104-109)

Received : 10.09.2011 Accepted : 02.12.2011 glomerular injury and glomerolusclerosis (GS) are generally unknown (3); however, it is thought that injury of podocytes, proliferative changes in endothelial, epithelial and mesangial cells, structural alterations in glomerular arterioles; and finally, development of sclerosis underlie this condition (4). A number of viruses, toxins and intraglomerular hemodynamic changes have been suspected as the culprits (5). On histopathologic examination a segmental perihilar

Correspondence: Rohollah Fadaei FOULADI

Department of Pathology, Tabriz University of Medical Sciences, Imam Reza Hospital, TABRIZ, IRAN

E-mail: Medicorelax@yahoo.com Phone: +98914412 2542 
or peripheral solidification of glomerular tuft usually with involvement of the tubular pole is common. However, histopathologic alteration in the renal tissue varies greatly, ranging from observation of normal glomeruli to segmental or global GS. Typical classification in this regard includes collapsing FSGS, cellular FSGS, tip-lesion, perihilar and nototherwise specified (NOS) (6). Although varying degrees of proteinuria along with hyaline and wide waxy casts may be detected in urinary analysis, red blood cell (RBC) casts are rare (7). As in other pathologies of the kidney, the serum creatinine and its clearance rate serve as valuable indicators of renal function $(8,9)$. However, they might lie in normal ranges in the early phase of the disease (10). It has been previously proposed that the renal function may reflect the extent of interstitial fibrosis (11-16), but this could not satisfyingly justify abnormalities in serum creatinine and its clearance in FSGS cases with no or mild interstitial fibrosis. It is not well recognized whether the serum creatinine or its clearance rate could be employed as good surrogates for the extent of segmentally or globally sclerosis of glomeruli in primary FSGS. Thus, this study aimed to assess the possible association between the extent of glomerular sclerosis and renal function in patients with FSGS and rather spared interstitial tissue.

\section{MATERIAL and METHODS}

In this cross-sectional study, 50 patients with biopsy-proven primary FSGS were recruited from Imam Reza Teaching Centre, Tabriz, Iran from March 2009 through July 2011. Cases with systemic diseases, primary or secondary glomerulopathies, a history of reflux and hepatitis B infection, and moderate to severe interstitial involvement in histopathologic assessment were not included. This study was approved by the Ethics Committee of Tabriz University of Medical Sciences and an informed consent was obtained from all participants at the time of enrollment.

A comprehensive evaluation, including a thorough historytaking and physical examination, as well as a complete laboratory evaluation such as urinalysis, 24-h urinary protein excretion, creatinine clearance $\left(\mathrm{C}_{\mathrm{Cr}}\right)$, serum and urinary levels of creatinine, cholesterol, albumin, fasting blood glucose, and other tests to exclude systemic diseases as appropriate, were performed at the time of initial evaluation. $\mathrm{C}_{\mathrm{Cr}}$ was calculated from the creatinine concentration in the collected urine sample $\left(\mathrm{U}_{\mathrm{Cr}}\right)$, urine flow rate $(\mathrm{V})$, and the plasma concentration $\left(\mathrm{P}_{\mathrm{Cr}}\right)$ by this formula (4):

$$
\mathrm{C}_{\mathrm{cr}}=\left(\mathrm{U}_{\mathrm{cr}} * \mathrm{~V}\right) / \mathrm{P}_{\mathrm{cr}}
$$

Potential confounding causes of creatinine rise were ruled out by a skilled nephrologist before histopathologic assess- ments. Renal specimens were obtained in all patients by percutaneous biopsy, and sections containing at least eight glomeruli were examined by a single skilled nephropathologist. Repeat biopsies following the diagnosis of FSGS were not included. The nephropathologist was blinded to the clinical and laboratory details of the patients.

The specimens were stained by Masson trichrome, Congo red, Periodic acid-Schiff (PAS) and Hematoxylin\&Eosin and examined by light microscopy and immunofluorescence (Olympus $^{\text {mix }}$, PA, USA). The immunofluorescence findings were as follows: positive IgM and C3, as well as negative IgG, $\mathrm{IgG}, \mathrm{C} 4, \mathrm{Clq}$ and fibrin/fibrinogen. On histopathologic assessment the interstitium showed mild to moderate patchy mononuclear inflammatory cell infiltration and fibrosis was mild and patchy. Tubular atrophy was about $30 \%$ up to $55 \%$ especially around affected glomeruli. Arterioles showed subintimal hyalinization and arteries show medial hypertrophy.

FSGS was defined based on the following criteria: (i) a lesion involving only some of the glomeruli in the biopsy with others remaining uninvolved, (ii) the involved glomeruli having a segmental sclerotic lesion with or without discrete capsular adhesions, and (iii) no clinical or pathological evidence for underlying primary disease that might produce secondary sclerosis.

Along with the first histopathological diagnosis of FSGS, segmentally and globally sclerosed glomeruli were counted separately in each field. At the same time, total glomerular count was also determined and then the proportion of segmentally and globally sclerosed glomeruli was calculated. The sclerotic score was determined based on following classification (6):

\section{I: Involvement $<25 \%$ of total glomeruli \\ II: Involvement of $26 \%-75 \%$ of total glomeruli \\ III: Involvement $>76 \%$ of total glomeruli}

To assess errors of measurement, total glomeruli, as well as the segmentally and globally sclerosed glomeruli were recounted in 10 specimens selected randomly on 2 consecutive days by the same observer. Data from the two sets of measurements were compared. The limits of agreements were acceptable (i.e. within the $5 \%$ of the mean value).

Correlations of the number and proportion of segmentally or globally sclerosed glomeruli with serum level of creatinine and its clearance rate were examined. Other investigated variables in the current study were the patients' age, gender and weight. 


\section{Statistical analysis}

Statistical evaluation was made using SPSS for Windows V 18.0 (SPSS Inc., Il, USA). The independent samples T-test, Mann-Whitney U-test, Chi-square test or Fisher's exact test were employed for comparison where appropriate. Correlation between different variables was examined by calculating the Spearman's rho coefficient. $\mathrm{P}$ values less than 0.05 were regarded as significant.

\section{RESULTS}

Demographics and general data of the studied population are outlined in Table I. Correlations between the proportion of sclerosed glomeruli and different variables are summarized in Table II. The proportion of segmentally sclerosed glomeruli was significantly correlated with the serum level of creatinine directly (Figure 1), and the creatinine clearance rate inversely (Figure 2). Similar relationships were also present between the proportions of globally sclerosed glomeruli and the mentioned variables (Figures 3 and 4). The other correlations did not reach statistically significant levels. In comparison between the males and females, neither the mean proportion of segmentally sclerosed glomeruli $(45.49 \pm 22.71$ and $43.53 \pm 19.68$, respectively; $\mathrm{p}=0.86)$, nor the mean proportion of globally sclerosed glomeruli $(36.11 \pm 16.23$ and $30.19 \pm 12.77$, respectively; $\mathrm{p}=0.16$ ) were significantly different. Associations of the glomerulosclerotic scores with the level of serum creatinine and its clearance rate are summarized in Table III. Accordingly, the median level of serum creatinine was significantly higher in patients with scores II or III segmental or global GS comparing with those in patients with score II segmental or global GS. Median

Table I: Demographics and general data of the studied patients with focal segmental glomerulosclerosis

\begin{tabular}{|c|c|c|}
\hline \multicolumn{2}{|l|}{ Variable } & Value \\
\hline \multicolumn{2}{|c|}{ Age (year) } & $39.82 \pm 16.45(16-85)$ \\
\hline \multicolumn{3}{|c|}{ Gender } \\
\hline & Male & $24(48)$ \\
\hline & Female & $26(52)$ \\
\hline \multicolumn{2}{|c|}{ Weight $(\mathrm{kg})$} & $63.58 \pm 10.24(47-87)$ \\
\hline \multicolumn{3}{|c|}{ Serum creatinine } \\
\hline & Level (mg/dl) & $3.60 \pm 2.30(1.6-10.6)$ \\
\hline & Clearance (hour ${ }^{-1}$ ) & $25.23 \pm 10.23(4.2-51.8)$ \\
\hline \multicolumn{2}{|c|}{ Total glomerular count } & $12.50 \pm 4.24(3-31)$ \\
\hline \multicolumn{3}{|c|}{ Segmentally sclerosed glomeruli } \\
\hline & Count & $4.44 \pm 3.05(1-13)$ \\
\hline & Proportion (\%) & $39.37 \pm 21.84(10-78.6)$ \\
\hline & Score $(\mathrm{I})$ & $20(40)$ \\
\hline & Score (II) & $28(56)$ \\
\hline & Score (III) & $2(4)$ \\
\hline \multicolumn{3}{|c|}{ Globally sclerosed glomeruli } \\
\hline & Count & $3.78 \pm 2.29(0-10)$ \\
\hline & Proportion (\%) & $33.03 \pm 14.69(0-62.5)$ \\
\hline & Score (I) & $17(34)$ \\
\hline & Score (II) & $33(66)$ \\
\hline
\end{tabular}

Data are presented as mean \pm standard deviation (range) or frequency (percentage).

Table II: Correlations between the proportion of sclerosed glomeruli and other variables

\begin{tabular}{|l|c|c|}
\hline Variables & rho & P-value \\
\hline Proportion of segmentally sclerosed glomeruli with age & -0.05 & 0.74 \\
\hline Proportion of segmentally sclerosed glomeruli with serum creatinine & 0.60 & $<\mathbf{0 . 0 0 1}$ \\
\hline Proportion of segmentally sclerosed glomeruli with creatinine clearance arte & -0.43 & $\mathbf{0 . 0 0 2}$ \\
\hline Proportion of globally sclerosed glomeruli with age & -0.19 & 0.18 \\
\hline Proportion of globally sclerosed glomeruli with serum creatinine & 0.64 & $<\mathbf{0 . 0 0 1}$ \\
\hline Proportion of globally sclerosed glomeruli with creatinine clearance rate & -0.45 & $\mathbf{0 . 0 0 1}$ \\
\hline
\end{tabular}

Table III: Association between the glomerulosclerotic scores and level of serum creatinine and its clearance rate

\begin{tabular}{|l|c|c|c|c|c|c|}
\hline \multirow{2}{*}{ Serum creatinine } & \multicolumn{2}{|c|}{ Segmental GS } & \multicolumn{3}{c|}{ Global GS } & \\
\cline { 2 - 7 } & Score I & Score II or III & P & Score I & Score II & P \\
\hline Level $(\mathrm{mg} / \mathrm{dl})$ & 2.3 & 3.3 & $<.001$ & 2.3 & 3 & $\mathbf{. 0 0 1}$ \\
\hline Clearance rate $\left(\right.$ hour $\left.^{-1}\right)$ & 28.3 & 23.2 & .09 & 30.3 & 21.4 & $\mathbf{. 0 0 3}$ \\
\hline
\end{tabular}

Data are presented as median. GS: Glomerolusclerosis. 


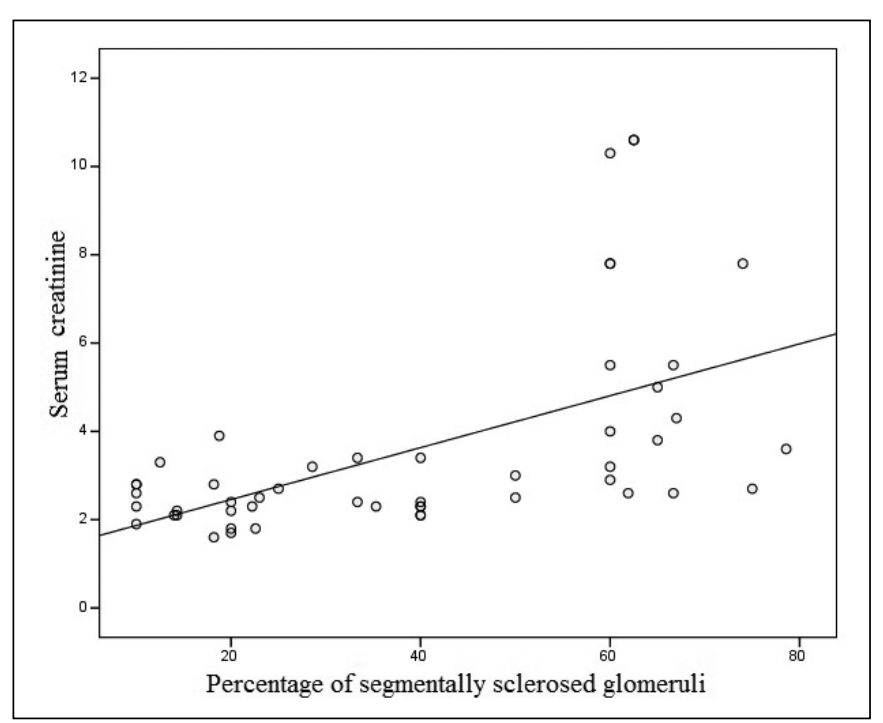

Figure 1: The scatter diagram of segmentally sclerosed glomeruli versus serum creatinine.

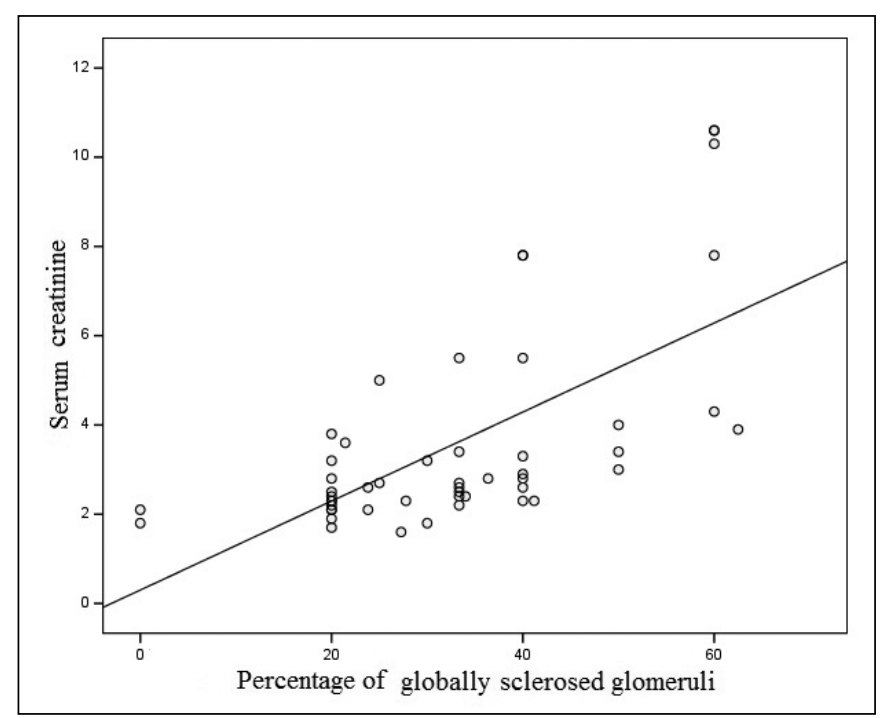

Figure 3: The scatter diagram of globally sclerosed glomeruli versus serum creatinine.

clearance of creatinine was significantly higher in patients with score I global GS comparing with that in patients with score II global GS.

\section{DISCUSSION}

The natural course of FSGS is gradual and progressive compromise of renal function and finally, development of ESRD within 5-10 years. Nevertheless, this course is variable and the prognosis may be unpredictable. So, many efforts have been ever made to employ some clinical and histopathologic aspects of the disease to predict its course (10). Serum creatinine and its clearance have been proposed in this regard; however, the data are scarce and

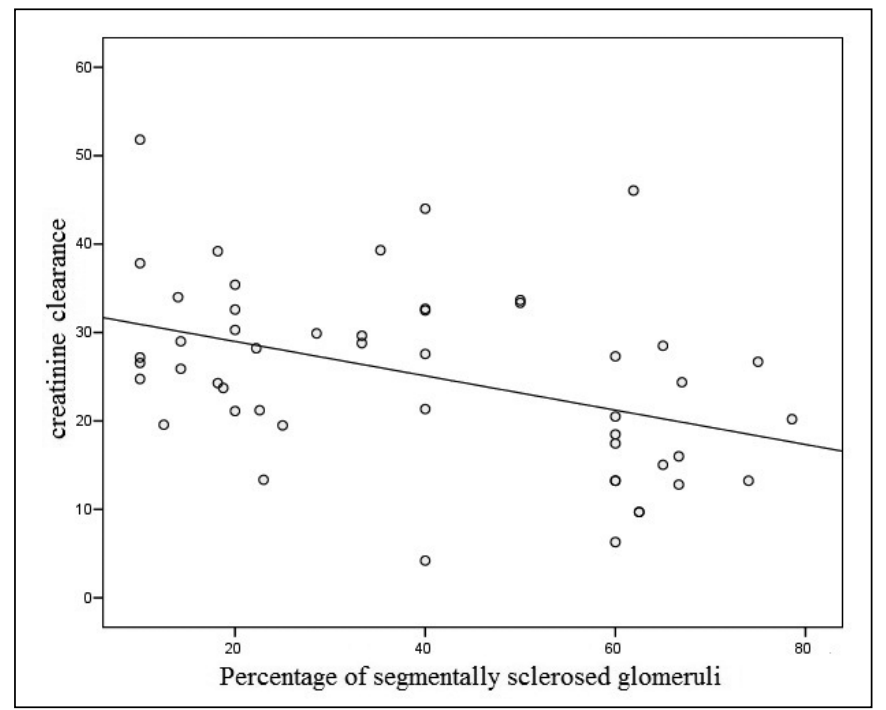

Figure 2: The scatter diagram of segmentally sclerosed glomeruli versus creatinine clearance.

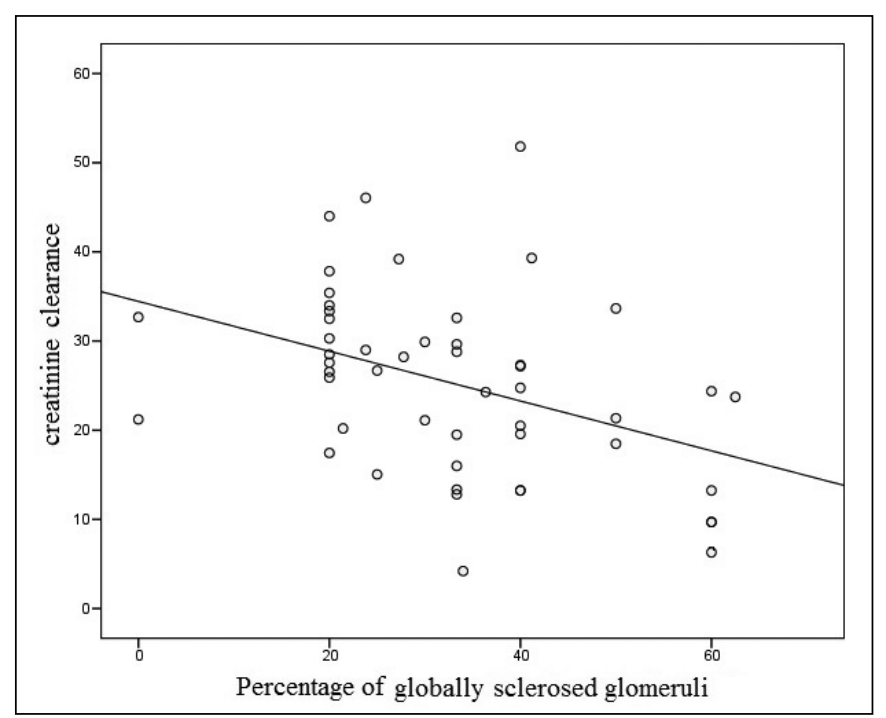

Figure 4: The scatter diagram of globally sclerosed glomeruli versus creatinine clearance.

inconclusive (6). In this study correlations between the number of sclerosed glomeruli in one hand, and serum level of creatinine and its clearance rate in other hand were investigated in patients with primary FSGS. Based on the findings, there were significant direct correlations between proportions of segmental or global GS and serum level of creatinine. There were also inverse correlations between proportions of segmental or global GS and clearance of serum creatinine. In one of avant-garde studies, Lee and Spargo recruited 60 patients with idiopathic FSGS and showed that the severity of renal hyaline arteriosclerosis and global GS was correlated well with the serum level of creatinine and its clearance rate (11). Their findings are 
partly in line with ours, namely in association of global GS and serum level of creatinine and its clearance rate. On the contrary, however, Chiang et al. did not find any significant association between the severity of vacuolization in epithelial cells and clearance of creatinine in 10 patients with primary FSGS (12). Although small sample size was a major limitation, this study may indicate indirectly that other histopathologic changes rather than vacuolated epithelial cells may be connected to changes in serum level of creatinine in patients with FSGS. Schwartz et al. studied 81 patients with primary FSGS and showed a significant direct association between the serum level of creatinine and degree of interstitial fibrosis. However, similar associations were not significantly apparent with the extent of segmental scar, diffuse mesangial hypercellularity and presence of lesions in glomerular epithelial cells (13). A wide range of histopathologic changes has been described in patients with FSGS and these may very greatly in even clinically similar cases. This variability may be regarded as one of the underlying etiology of heterogeneity in different settings. Another example is the results of study by Lee and Kim on 11 patients with primary FSGS. They reported significant reverse association between the ratio of mesangial volume and clearance of creatinine and direct association between the size of basal membrane of peripheral glomeruli and clearance of creatinine. However, they did not report any significant association between the density of interstitial volume and clearance of creatinine (14). In another series by Rydel et al. on 81 patients with primary FSGS, there was significant direct association between the serum level of creatinine and degree of interstitial fibrosis (15). Danilewicz et al. enrolled 15 patients with primary FSGS in their study. There was a significant direct association between the interstitial volume and serum level of creatinine, as well as significant correlations between the volume of glomerular mesangium and total glomerular area with serum creatinine. They concluded that the glomerular hypertrophy and interstitial fibrosis are valuable predictors of prognosis in patients with primary FSGS (16). In a recent study by Taheri et al., 64 patients with primary FSGS were assessed. There were direct associations between the serum level of creatinine and extent of adhesions in Bowman's capsule, interstitial fibrosis and global scar (10). It is clear that the sclerotic changes in glomeruli of patients with FSGS may lead to interstitial fibrosis (6). By the way, it is generally accepted by pathologists that a shared feature in all cases with FSGS is the sclerosis (4). However, it should be born in mind that our study is the first one which deals with association of glomerular sclerosis and changes of serum creatinine and its clearance in a totally quantitative fashion. Likewise, our selecting criteria in terms of concomitant histopathologic changes in the interstitium have restricted interfering effects of other histopathologic changes routinely seen in patients with FSGS other than the glomerular sclerosis. Overall, unlike previous reports which focused on the role of histopathologic changes in the interstitial tissue in alteration of renal function in FSGS, we showed exclusively that glomerular sclerosis should not be overlooked in this regard.

\section{CONCLUSION}

Serum level of creatinine and its clearance rate are good indicators of extent and severity of segmental or global glomerular sclerosis in patients with primary FSGS. This association seems to be distinct from others, particularly that one between the interstitial histopathologic changes and function of kidney in these patients.

\section{REFERENCES}

1. Chun MJ, Korbet SM, Schwartz MM, Lewis EJ: Focal segmental glomerulosclerosis in nephrotic adults: presentation, prognosis, and response to therapy of the histologic variants. J Am Soc Nephrol 2004, 15:2169-2177

2. Crook ED, Habeeb D, Gowdy O, Nimmagadda S, Salem M: Effects of steroids in focal segmental glomerulosclerosis in a predominantly African-American population. Am J Med Sci 2005, 330:19-24

3. D'Agati V: The many masks of focal segmental glomerulosclerosis. Kidney Int 1994, 46:1223-1241

4. Brenner BM: Brenner and Rector's The Kidney. 6th ed., USA, Saunders, 2000

5. Korbet SM: Treatment of primary focal segmental glomerulosclerosis. Kidney Int 2002, 62:2301-2310

6. Jennette JC, Olson JL, Schwartz MM, Silva FG: Heptinstall's Pathology of the Kidney. 6th ed., USA, Lippincott Williams, 2006

7. Valeri A, Barisoni L, Appel GB, Seigle R, D'Agati V: Idiopathic collapsing focal segmental glomerulosclerosis: a clinicopathologic study. Kidney Int 1996, 50:1734-1746

8. Atangwho IJ, Ebong PE, Eteng MU, Eyong EU, Obi AU: Effect of vernonia amygdalina del leaf on kidney function of diabetic rats. Int J Pharmacol 2007, 3:143-148

9. Abdin AA, Draz EI, Sarhan NI: Evaluation of the chemoprotective role of $\mathrm{N}$-Acetylcysteine on cisplatininduced nephrotoxicity: New aspect of an old drug. Int J Pharmacol 2008, 4:339-351

10. Taheri D, Chehrei A, Samanianpour P, Hassanzadeh A, Sadrarhami S, Seyrafian S: Correlation of kidney biopsy findings and clinical manifestations of primary focal and segmental glomerulosclerosis. Saudi J Kidney Dis Transpl 2009, 20:417-423

11. Lee HS, Spargo BH: Significance of renal hyaline arteriolosclerosis in focal segmental glomerulosclerosis. Nephron 1985, 41:86-93 
12. Chiang ML, Hawkins EP, Berry PL, Barrish J, Hill LL: Diagnostic and prognostic significance of glomerular epithelial cell vacuolization and podocyte effacement in children with minimal lesion nephrotic syndrome and focal segmental glomerulosclerosis: an ultrastructural study. Clin Nephrol 1988, 30:8-14

13. Schwartz MM, Korbet SM, Rydell J, Borok R, Genchi R: Primary focal segmental glomerular sclerosis in adults: prognostic value of histologic variants. Am J Kidney Dis 1995, 25:845-852
14. Lee HS, Kim TS: A morphometric study of preeclamptic nephropathy with focal segmental glomerulosclerosis. Clin Nephrol 1995, 44:14-21

15. Rydel JJ, Korbet SM, Borok RZ, Schwartz MM: Focal segmental glomerular sclerosis in adults: presentation, course, and response to treatment. Am J Kidney Dis 1995, 25:534-542

16. Danilewicz M, Wagrowska-Danilewicz M: Minimal change disease and idiopathic focal segmental glomerulosclerosis in adults. A quantitative study. Pol J Pathol 1996, 47:209-214 